\title{
Indian Handloom Sector - A Glimpse
}

\author{
Gunti Amaravathi, K. Bhavana Raj
}

\begin{abstract}
Handloom sector in India is an important unorganized, diversified, decentralized, huge employment provider, good contributory to an economy, eco-friendly, family and rural-based; artistic and heritage. This paper is animated to analyze the important elements of the handloom sector such as dependent households, weavers, looms, worked man-days; production trends, export trends, and imports.
\end{abstract}

\section{INTRODUCTION}

The term handloom is defined as "any loom other than power loom" (The Reservation of Articles for Production Act, 1985)[1]. The concept of the handloom industry includes the process of operation by hand, of a wooden structure which is called the loom. In India, the handloom sector is one of the largest unorganized economic activities after agriculture and constitutes an integral part of the rural and semi-rural areas. It is ancient, cultural heritage, traditional, decentralized, family-based, laborious, artistic skill and transfer of skills from one generation to another. In every stage of production like warping, dying, winding, weaving, etc., family members inputs labor.Weavers are mainly from the vulnerable and weaker sections of society, who generally weave for their livelihood. The diversity in India has been seen in the Indian handloom sector also, like in products, designs, weaving styles, usage of looms, employment status, economic position, etc., every state continuing their heritage and culture. In India, the handloom sector spread across the country and providing employment to nearly 43 lakhs and 28 lakhs households are depended on this sector.The 65 percent of handloom households distributed in northeastern states such as Assam, Meghalaya, Nagaland, Arunachal Pradesh, etc., and remaining in major states such as erstwhile Andhra Pradesh, Tamilnadu, Orissa, West Bengal and in other states. This sector has been able to withstand competition from the mill and power loom sector ( $3^{\text {rd }}$ Handloom Census, Ministry of Textiles, GOI) [2]. For prevention from counterfeit products and unauthorized use, and protection of handloom artistry, 57 handloom products have been registered under the Geographical Indications of Goods (Registration \& Protection) Act 1999 (Annual Report 2017-18,Ministry of Textiles, GOI) [3].

\section{LITERATURE REVIEW:-}

Mr. Ashish Kumar, Dy. General Manager, Ms. SimaranKaur, Manager (2018), analyzed the characteristics of the handloom sector in India, export and import trends in handloom, different government schemes for the upliftment of the handloom sector.Handloom sector is being facing various problems such as competition frompower loom and

Revised Manuscript Received on April 12, 2019.

GuntiAmaravathi, Research Scholar, Department of Commerce \& Management, KLEF (Deemed to be University) Campus: Green Fields, Vaddeswarm, Guntur District.A.P, India.

Dr. K. Bhavana Raj, Department of Management Studies, KLHBS, Hyderabad.Telanaga, India. mill sector, shortage of raw materials, lack of credit availability, marketing issues, institutional inefficiencies, paucity of novelty in designs, inconvenient working conditions, unorganized nature of industry, insufficient research and training, inappropriate quality of designs, lack of information on schemes and reduction in number of weavers. They suggested various strategies for development of handloom sector such as increasing quality and availability of raw materials, encourage renewed designs, adoption of effective marketing strategies, creating a niche premium market, enhancing efficiency of PWCS, extension of credit, market diversifications, infrastructural development, product diversification, quality up-gradation and increased emphasis on packaging, adopting cluster development approach, spreading awareness, improve working conditions and strengthen handloom database [4].

Shilpi Jain, SripurnaBasu, BishkaMajumdar,(2018),research focus on the problems, experience and, consequences in the adoption of information technology in the handloom sector in India, and the factors that facilitate the adoption of internet for the growth of this sector. ICT platforms can be effectively utilized to design and develop an ecosystem with Wireless for Communities (W4C) model to provide internet connectivity to remote villages. It can solve the major problem of rural poverty. It can possible through the creation of small entrepreneurship, the spread of education and social empowerment, and reinventing core competencies to better leverage them with more impact in changing times [5].

ThirupathiKandikonda, and AnakamSreenivas (2017), focused on the work nature of different types of weavers, varieties of cloths and schemes in Telangana.Weavers are categorized as an independent weaver, master weaver, cooperative weaver, weaver under the middle man and labor weaver. Cloth varieties are ikatsarees, cotton and durries, python sarees, jacquard, and art silk. The government is intending to bring the handloom weavers into the cooperative fold in a phased manner for channelizing the aid through the Weavers co-operative societies. The government is implementing different schemes under a five-year plan, such as capital loans, modernization of looms, interest subsidy, thrift fund-cum-savings security schemes and work shed-cum-housing scheme [6].

Dr. Esha Jain, AshankYadav (2017), highlighted the developments of modern technology and influence on marketing.Technology and communication help in the development of business in all aspects including marketing. Digital marketing platforms like websites, apps, emails and social networks, digital marketing devices like smartphones, personal computers and tablets promotes the products and

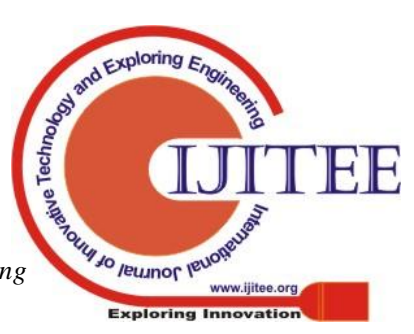


provide services to consumers. Comparing to non-digital marketing and traditional marketing, digital marketing allows the marketer to conduct surveys and campaigns, target and track with a laser focus to specific groups, etc., with the usage of technical tools in many aspects and Return on Investment more accurately. A combination of technology and marketing, industry grow rapidly and gain smart returns could never have been achieved. Change in technology, reflecting a significant change in marketing also [7].

A. Arul Prakash, Dr.A.Selvendran (2017), the study examined the Silk handloom industry, production process, of silk handloom sarees, the process of Seri-culture, problems relating to the production of silk sarees, financial problems of Silk handloom societies, availability of raw material and marketing problems. The industry is facing big challenges such as undertaking modifications according to customer preferences, production diversification, and deployment of modern technology. They found the objective of the establishment of Zari testing units in Kanchipuram for testing of gold and silver content in zari is to regain the reputation and confidence of consumers due to the reduction of gold and silver content in the zari. The author focused on the measures taken by the government for the abolishment of child labour in the Kanchipuram silk handloom industry.Suggested to the government for strategies to be implemented for providing a minimum of 300 work hours to weavers under co-operative fold [8].

Dr. SabihaKhatoon (2016), analyzed the role of the Indian handloom sector in the textile industry, challenges faced by the handloom sector different schemes implemented by the government of India for the development of the handloom sector. The challenges are a shortage of yarn, higher price of raw material, and unavailability of good quality dye, credit availability, market facilities, limited design support, and poor working conditions.the study suggested, different measure to be taken for the development of handloom industry to avail the benefits of 'Make in India' program as a platform such as attracting foreign customers by showing the beauty of products, strengthen in the international market. Further, recommendations include the conduct of skill development programs, product quality assurance, cost control, technology up-gradation, arevival of traditional handloom and providing market avenues [9].

KalyanSarkar (2016), analyzed the health issues being faced by the weavers and suggested measures to uplift weavers in various aspects. Weavers are suffering from different health issues like back pain, neck pain, foot pain, and joint pain. The reasons for health problems are poor ergonomic design at the workplace and no safety measures being followed at the workplace. The researcher recommended that the government should take legislative measures to provide hygienic, clean and safe environments at the workplace, the conduct of awareness programs on health issues and the conduct of regular health camps to monitor weaver's health condition [10].

Dr. SumanaChatterjee (2015), analyzed the small scale units in the textile sector in Gujarat. Examined production information and operational wise operation costs of different sectors of the textile industry such as handloom, power loom, mill, hosiery, garments, etc. and specialized clusters in the state. He found conventional textiles like ginning and processing, cotton knitwear, etc, and technical textiles such as agro textiles, geotextiles, etc. [11].

BhabeshHazarikaMadhurjyaPrashadBezbaruah, KishorGoswami (2015), opined that technological upgradation is important for the handloom sector to tolerate competitiveness. The study focused on factors and problems related to the adoption of technology in rural, nonfarm, and informal micro-entrepreneurs in Assam.Examined the role of key issues such as financial inclusion, family labor contribution and social network in technology adoption. The interaction and sharing of information through a social network are likely to promote technology adoption among the potential adopters. Financial inclusion of handloom micro-entrepreneurs through banks, non-banking credit societies, self-help groups (SHGs) may be regarded as a promoter for increasing the rate of technology adoption. Comparing to small firms, big firms have different problems like lack of resources, labour shortage, and complexity in structure. The study suggested, a comprehensive policy framework for the availability of credit or capital, market linkages, and extension services to promote technology adoption among the rural micro-entrepreneurs [12].

TasneemShazli(2014), analyzed the female work participation in the handloom industry, especially in Mubarakpur town, Uttar Pradesh.He found that female weavers are facing various problems such as poverty because of gradually declined the handloom industry due to intra-riots which have hampered the trade, competition from power loom, health problems due to the involvement of physical work, level of education and health facilities are very poor. Suggested that, the government should take initiation for qualitative modification, guidance, and protection for the balanced development of the handloom industry [13].

Dr. RachanaGoswami, Dr. Ruby Jain (2014), analyzed the problems being faced by the handloom sector such as low sales, lack of scientific market research, insufficient budget, lack of proper infrastructure, etc., due to not following suitable strategies in different activities. Further, they suggested strategies like overall cost leadership, product differentiation, etc. to gain profits in the handloom sector [14].

Alin Borah Bortamuly, KishorGoswami, BhabeshHazarika, KalpanaHandique (2014), analyzed the determinants of entrepreneurship development in the handloom industry based on gender and location, especially in Assam. Work experience and education play a crucial role in the development of entrepreneurship in females and also in rural areas compared to male and urban areas. The involvement of family members in handloom work plays an important role in the development of handloom entrepreneurship. Suggested for development of rural handloom markets for the development of handloom entrepreneurship among females [15].

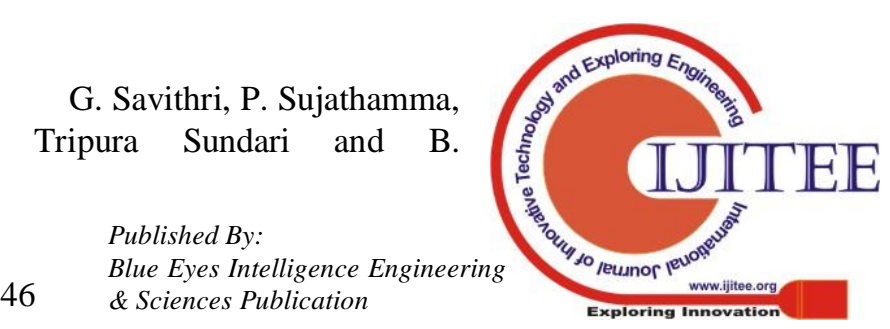


Chandan Kumar (2014), examined the importance of the geographical Indication (GI) Act, 1999, which protects artistry and skill involvement products and prevents from counterfeit and unauthorized use. Pochampally products gaining brand image, greater rich in the domestic and international market and geographical fame because of getting 'GI' status to PochampallyIkat designs [16].

NoopurTandan, E Eswara Reddy (2013), researchers presented an overview of the textile industry in the international market, the share of the Indian textile industry in the international market and the initiations taken by the Government of India to strengthen the textile industry in their article.The researchers opined that different schemes, skill development programs, and marketing assistance programs would behave the potential to increase the contribution of the textile industry in the share of GDP and that globalization has had a positive impact on the exports of Indian textiles [17].

Dr. SrinivasaRaoKasisomayjula (2012), analyzed the socio-economic conditions of handloom weavers especially in Andhra Pradesh, textile and handloom industry structure, production and marketing trend, the financial performance of co-operative societies. They found that annual average income of the handloom households is doubled, but in real terms, it comes down due to annual inflation, raw material, and dyes rates are increased, most of the weavers are under poverty and underemployment.Weavers are suffering from ill-health and family burdens, they are not maintaining specific work hours. The financial performance of APCO and Weavers' co-operative societies is not satisfactory [18].

Suresh Bhagavatula, Tom Elfring, Aadvan Tilburg, Gerhard G. Van de Bunt (2010), focused on the role and problems of the master weavers in the handloom sector.Master weavers are working efficiently in the reduction of operational cost and implementing social network strategy in the development of their business. Master weavers are plying a crucial role in the handloom industry for surviving and making handloom extremely competitive. Master weavers have to collect products which are produced in different areas and as well as has to market these products to retail stores which are spread across various areas. They are depending mostly on unorganized financial systems for meeting their financial needs.Researchers evaluated that, Master weavers sales transactions are mostly on credit and have been facing difficulty in recovering money from the textile shops and resulting in bad debts [19].

AlokNath Roy, GautamBasu (2009), examined the problems during the production of jute based decorative fabrics with ornamental effect in traditional cotton handloom with jacquard shedding arrangements. The weaving of jute carpets in handloom is an old practice.Production of specialty jute fabric by using lignocellulosic fibers as both warp and weft, which has been improved the terms of colour, luster, fineness, etc. to the jute products, is in infancy stage in handloom. To alleviate the problem in weaving jute based decorative fabrics with ornamental effects in handloom, developed a large size double beam let-off and automatic take-up arrangement handloom modifying the traditional jacquard shedding arrangement. With the advent of technological changes reflected in handloom for the production of fine quality fabric [20].

KKN Kurup (2008), analyzed the traditional handloom industry in Kerala. In Kerala, Idankai and Valankai sects of Padma Salyas community participate in spinning and weaving activities respectively. They have produced handloom products like Mundu, Thortu, Veshti, and Pudava. The advent of technological changes, most of the traditional pit looms replaced with wooden framed looms and further handloom sector changed to factory pattern from cottage industry.Further, he found that the Government of Kerala is taken initiations for the development of industry like all the weavers are brought into the co-operative fold and cooperative societies are supplying required yarn and receive back the finished goods. Rebate system on handloom products on particular festivals, request to employees, teachers, and students to wear handloom on Saturdays, etc. [21].

Dharmaraju P (2006), analyzed the working of handloom cooperatives in Angara and Koyalgudem in Andhra Pradesh. Weavers' cooperatives are established initially with the objective of providing yarn to the weavers at subsidized rates, later they involved in marketing and other activities. Over the decades, cooperatives are controlled by master weavers and local political leaders. Government of Andhra Pradesh passed Mutually Aided Cooperative Societies (MAC) Act, 1995, cooperative societies entered into the production and marketing activities. Koyalagudem cooperative society capitalized on ikat design unique products and sell these at exhibitions, national and international markets. During the ikat boom, it performs good export business. Ban on chemical dyes by European markets, to cut costs, weavers used cheaper dyes, as a result of the export business badly damaged and weavers lost their world market. He suggested that, explore the domestic market is important in addition to the international market to cooperatives [22].

SeemanthiniNiranjan, SoumyaVinayan (2001), presented an overall picture of the handloom industry, types of weavers, source of capital, market adaptability, migration of weavers, weavers under the cooperative fold in especially in some of the villages, it includes Chirala, Yemmiganoor, Koyalagudem of southern states. They assessed that weavers not able to work independently, and most of them working under master weavers due to insufficient capital, improper marketing mechanism, etc. They suggested strategies such as assessing the policy framework, credit needs, and inputs support, product reservations, research needs, market needs, correcting misperceptions, etc. [23].

RatanKhasnabis, Pranab Nag (2001), analyzed the labour process in a transitional situation in the informal weaving sector, particularly in Naidal district. He examined the Mahajan system who controls the weavers, production process in handloom, division of labour, capitalism and wage labour. Found that, small weavers are worked in the Mahajan system, which resulted in the deskilling tendency in labour process because of the involvement of the Mahajan 
who controls capital and market, and the masters who plan the production, the weavers remain like wage labour. Deskilling is the bondage relation between direct producer and the Mahajan. A tiny section of one-loom owners remains outside the Mahajan system and maintain a precapitalist labour process and performs all process of production. Some sections of the multi loom owners operate outside the Mahajai system, and they concentrate on planning only due to large scale operations and involves outside labour as a weaver. A separation between planning and execution in the labour process, the owner-producer thus developed this sector through technology process, whereas weaving worker has only labour-power to sell, execute the work schedule and remained as a deskilled worker.Usury and merchant capital capture the development of capitalism in the handloom sector [24].

AnupamaTakur (1995), focused on various issues faced by the Indian handloom industry within the framework of Michael Porter's 'Competitive strategy', and found the problems such as buyers, threats from substitute products, suppliers and threats from new entrants. He opined the need for private entrepreneurs to enter the handloom sector [25].

Clark Nardinelli (1986), analyzed the impact of technological progress on the handloom sector, the problem of handloom weavers based on the technological differences between handloom weaving and power loom weaving. In the long run, technological progress was far more rapid in power loom weaving compared to handloom weaving. He found that the effect of technological development was to increase the rate of cyclical unemployment only and cause of unemployment due to a downturn in demand. Weavers and Perspective weavers turned to alternative employment after power loom replaced the handloom, and handloom weavers suffered a severe decline in their standard of living due to technological development in power loom weaving. Technological, cyclical and secular problems caused by technological development and it did not include technological unemployment [26].

\section{GAPS IN LITERATURE:-}

The review of the literature makes it obvious that there is a considerably large number of studies on the prospects of the handloom sector, socio-economic problems, entrepreneurship development, role of women, government schemes and subsidies, etc. But hardly there is any evidence of conducting a study on the outlook of the Indian handloom industry at a glance. This gap will be cemented with the following objectives.

\section{OBJECTIVES:-}

1. To examine the important elements of the Indian handloom sector census wise.

2. To analyze the production of the handloom sector in India.

3. To analyze the export and import of handloom products in India.

\section{METHODOLOGY:-}

The above objectives are accomplished with the help of secondary data. The data/statistics on the distribution of handloom households, weavers, looms and important elements of handloom, handloom production, export and import of handloom varieties will be collected from various sources such as government reports, articles, and online.

\section{IMPORTANT ELEMENTS OF INDIAN HANDLOOM SECTOR:-}

In India, the first time in $1887-88$, conducted national handloom census for creating a database to provide inputs for policy-making purposes and so far three national handloom census were conducted. Important elements of the handloom sector are like handloom households, looms, handloom workers, cloth production, man-days, employment status, the contribution of income, etc. The trend of important elements of the handloom sector is as follows:

Table 1: Handloom Census Wise Summary of Handloom Sector

\begin{tabular}{|c|c|c|c|c|c|c|c|}
\hline $\begin{array}{l}\text { Sl. } \\
\text { No. }\end{array}$ & Elements & $\begin{array}{c}\text { First } \\
\text { census } \\
(\mathbf{1 9 8 7 - 8 8})\end{array}$ & $\begin{array}{c}\text { Second } \\
\text { census } \\
(1995-96)\end{array}$ & $\begin{array}{c}\text { Third } \\
\text { census } \\
(2009- \\
10)\end{array}$ & $\begin{array}{l}\% \text { of } \\
\text { change } \\
\text { from } 1^{\text {st }} \\
\text { census to } \\
2^{\text {nd }} \text { census }\end{array}$ & $\begin{array}{c}\% \text { of } \\
\text { change } \\
\text { from } \\
2^{\text {nd }} \text { census to } \\
3^{\text {rd }} \text { census }\end{array}$ & $\begin{array}{c}\% \text { of } \\
\text { change } \\
\text { from } 1^{\text {st }} \\
\text { census to } \\
3^{\text {rd }} \text { census }\end{array}$ \\
\hline 1 & Handloom units (Lakhs) & 29.97 & 25.24 & 27.83 & $-16 \%$ & $10 \%$ & $-7 \%$ \\
\hline 2 & Weavers \& Allied Workers(Lakhs) & 67.4 & 65.5 & 43.32 & $-3 \%$ & $-34 \%$ & $-36 \%$ \\
\hline 3 & $\begin{array}{l}\text { Percentage-wise distribution of gender } \\
\text { and children in handloom sector -Men } \\
\text { Women } \\
\text { Children }\end{array}$ & - & $\begin{array}{c}30 \% \\
62 \% \\
8 \%\end{array}$ & $\begin{array}{l}20 \% \\
69 \% \\
11 \%\end{array}$ & - & $\begin{array}{c}-10 \% \\
7 \% \\
3 \%\end{array}$ & - \\
\hline 4 & No. of Handlooms(Lakhs) & 37.8 & 34.71 & 23.77 & $-8 \%$ & $-32 \%$ & $-37 \%$ \\
\hline 5 & Share of Idle looms to total looms & $7 \%$ & $10 \%$ & $10 \%$ & $43 \%$ & $-6 \%$ & $3 \%$ \\
\hline 6 & $\begin{array}{l}\text { Share of full-time adult weavers to } \\
\text { total adult weavers }\end{array}$ & $52 \% *$ & $48 \% *$ & $63 \% * *$ & $-8 \%$ & $15 \%$ & $11 \%$ \\
\hline
\end{tabular}




\begin{tabular}{|l|l|c|c|c|c|c|c|}
\hline 7 & $\begin{array}{l}\text { Percentage of independent weavers to } \\
\text { total weavers }\end{array}$ & $54 \%$ & $60 \%$ & $61 \%$ & $11 \%$ & $1 \%$ & $7 \%$ \\
\hline 8 & $\begin{array}{l}\text { Handloom cloth production( million } \\
\text { square meters) }\end{array}$ & 4370 & 7202 & 6806 & $65 \%$ & $-5 \%$ & $56 \%$ \\
\hline 9 & $\begin{array}{l}\text { Share of handloom cloth to total cloth } \\
\text { production }\end{array}$ & $24 \%$ & $23 \%$ & $11 \%$ & $-4 \%$ & $-12 \%$ & $-13 \%$ \\
\hline 10 & $\begin{array}{l}\text { Share of handloom in the export of } \\
\text { total textile }\end{array}$ & $4.8 \% * * *$ & $1.3 \% * * *$ & $1.2 \%$ & $-73 \%$ & $-0.1 \%$ & $-3.6 \%$ \\
\hline 11 & $\begin{array}{l}\text { Man days worked by weaver } \\
\text { households during the census year }\end{array}$ & - & 197 & 234 & - & $19 \%$ & - \\
\hline 12 & $\begin{array}{l}\text { Share of handloom households } \\
\text { worked up to 150 man-days in a year }\end{array}$ & $36 \%$ & $31 \%$ & $33 \%$ & $-14 \%$ & $2 \%$ & $-8 \%$ \\
\hline 13 & $\begin{array}{l}\text { Percentage of weaver households } \\
\text { reporting less than a meter } \\
\text { production(weaving) per day }\end{array}$ & $49 \%$ & $68 \%$ & $46 \%$ & $39 \%$ & $-24 \%$ & $-3 \%$ \\
\hline 14 & $\begin{array}{l}\text { Share of weaver households } \\
\text { contributing more than 60 percent } \\
\text { income from handlooms and related } \\
\text { activities }\end{array}$ & $36 \%$ & $31 \%$ & $35 \%$ & $-14 \%$ & $4 \%$ & $-1 \%$ \\
\hline
\end{tabular}

(Source: Compiled from Handloom censuses and Annual reports of Ministry of Textiles, GOI)

*Information related to above 14 years.

***Information related to above 18 years

***Roy T. et al (1998), in Gulati, Preeti, Unpublished thesis, School of Planning, CEPT, Ahmedabad

Table 1 reveals that, handloom households are 30 lakhs in $1^{\text {st }}$ handloom census in the year 1987-88, in $2^{\text {nd }}$ handloom census 1995-96, these decreased to 25 lakhs i.e. 16 percentage, and these increased to 28 in $3^{\text {rd }}$ handloom census 2009-10 i.e. 10 percentage, overall there is a negative growth of 7 percentage from first handloom census to third handloom census.

Weavers and allied workers are 67 lakhs in $1^{\text {st }}$ handloom census, in the $2^{\text {nd }}$ census they are declined to 66 lakhs i.e. 4 percentage, but they are rapidly declined to 43 lakhs in $3^{\text {rd }}$ census i.e. 34 percentage and overall decrease is 36 percentage from $1^{\text {st }}$ census to $3^{\text {rd }}$ census. If we see the gender-wise distribution, it reveals the role of the women handloom workers is very important and their participation in handloom is increased by 7 percentage from $2^{\text {nd }}$ census to $3^{\text {rd }}$ census, As well as children participation also increased by 3 percentage but men participation had decreased by 10 percentage from $2^{\text {nd }}$ census to $3^{\text {rd }}$ census.

Handlooms are 38 lakhs in the $1^{\text {st }}$ census and whereas these are declined to 24 lakhs in the $3^{\text {rd }}$ census i.e. 37 percentage. Idle looms percentage is 7 in the $1^{\text {st }}$ census and whereas it is 10 percent in the $3^{\text {rd }}$ census. The share of full-time adult weavers to total adult weavers is increased from 52 percent in the $1^{\text {st }}$ census to 63 percent in the $3^{\text {rd }}$ census. The share of independent weavers is 54 percent in the $1^{\text {st }}$ census and it is increased to 61 percent in the $3^{\text {rd }}$ census.

Handloom cloth production is 4370 million $^{2}$ meters in the $1^{\text {st }}$ census, it increased to 7202 million $^{2}$ meters in the $2^{\text {nd }}$ census i.e. 65 percentage, and it decreased to 6806 million ${ }^{2}$ meters in the $3^{\text {rd }}$ census i.e. 5 percentage. However, cloth production increased by 56 percentage from the $1^{\text {st }}$ census to the $3^{\text {rd }}$ census. Share of handloom cloth to total cloth production is 24 percentage in the $1^{\text {st }}$ census, but it decreased to 11 percent in the $3^{\text {rd }}$ census and recorded 13 percent of negative change from $1^{\text {st }}$ census to $3^{\text {rd }}$ census. Share of handloom cloth export to total textile is 5 percentage in the $1^{\text {st }}$ census and it is 1 percentage only in $3^{\text {rd }}$ census i.e. decreased by 4 percentage.

Share of handloom units worked up to 150 man-days averagely in a year is 36 percent in the $1^{\text {st }}$ census and it is 33 percent only in the $3^{\text {rd }}$ census.No. of man-days worked during census year is increased by 19 percentage from $2^{\text {nd }}$ census to $3^{\text {rd }}$ census. 49 percent of households are weaving less than a meter per day in the $1^{\text {st }}$ census, it is increased to 68 percent in the $2^{\text {nd }}$ census, but it is declined to 46 percent in the $3^{\text {rd }}$ census. Share of handloom households contributing more than 60 percent income from handloom is 36 percentage is the $1^{\text {st }}$ census and it is 35 percent in the $3^{\text {rd }}$ census.

It reveals that handloom units, weavers \& allied workers and looms have been declining day by day and percent of idle looms are increasing. Share of handloom cloth to total cloth production and exports, the share of handloom income to total family income, etc. are declined from $1^{\text {st }}$ census to $3^{\text {rd }}$ census. It indicates that weavers are migrating to another profession due to many reasons such as generation of low income, insufficient working capital, insufficient marketing facilities (SeemanthiniNiranjan, SoumyaVinayan, 2001) [23], lack of technological up-gradation, inadequate credit availability, lack of contemporary designs, younger generation is not interested in taking handloom as a profession due to involvement of hard labour work (Status Quo in the Definition Of Handloom Under Handloom Reservation Act, 2014, Ministry of Textiles, GOI) [27]. 


\section{HANDLOOM CLOTH PRODUCTION:-}

The textile industry in India is the second largest industry after agriculture and a huge employment provider to both skilled and unskilled workers. In the textile industry different sectors such as mill, handloom, power loom, etc., are producing cloth.Production of cloth and their share in the total cloth production of different sectors are as follows during the period 2009-17:

Table 2: Textile production in India during the period 2009-2017 (Billion square meters)

\begin{tabular}{|c|c|c|c|c|c|c|c|}
\hline \multirow{2}{*}{ Year } & \multicolumn{2}{|c|}{ Mill } & \multicolumn{2}{c|}{ Handloom } & \multicolumn{2}{c|}{ Power loom } & Total cloth* \\
\cline { 2 - 8 } & Values & $\begin{array}{c}\text { \% of the } \\
\text { share }\end{array}$ & Values & $\begin{array}{c}\text { \% of the } \\
\text { share }\end{array}$ & Values & $\begin{array}{c}\text { \% of the } \\
\text { share }\end{array}$ & Thency \\
\hline $1990-91$ & 2.59 & 12.80 & 4.29 & 21.23 & 13.35 & 65.97 & 20.23 \\
\hline $2000-01$ & 1.67 & 5.06 & 7.51 & 22.76 & 23.80 & 72.18 & 32.98 \\
\hline $2009-10$ & 2.02 & 4.41 & 6.81 & 14.86 & 37.00 & 80.75 & 45.82 \\
\hline $2010-11$ & 2.21 & 4.69 & 6.91 & 14.66 & 38.02 & 80.67 & 47.13 \\
\hline $2011-12$ & 2.31 & 4.95 & 6.9 & 14.79 & 37.45 & 80.26 & 46.66 \\
\hline $2012-13$ & 2.42 & 5.10 & 6.95 & 14.66 & 38.04 & 80.24 & 47.41 \\
\hline $2013-14$ & 2.53 & 5.45 & 7.1 & 15.29 & 36.79 & 79.24 & 46.43 \\
\hline $2014-15$ & 2.49 & 5.25 & 7.2 & 15.18 & 37.75 & 79.57 & 47.44 \\
\hline $2015-16$ & 2.32 & 4.94 & 7.64 & 16.28 & 36.98 & 78.78 & 46.94 \\
\hline $2016-17$ & 2.26 & 4.92 & 8.01 & 17.44 & 35.67 & 77.64 & 45.94 \\
\hline
\end{tabular}

(Source: Office of the Textile Commissioner, Government of India)

*In total cloth production, hosiery, khadi, and wool have not been considered.

\section{Chart 1: Sector-wise share of textile production in} India in the year 2016-17

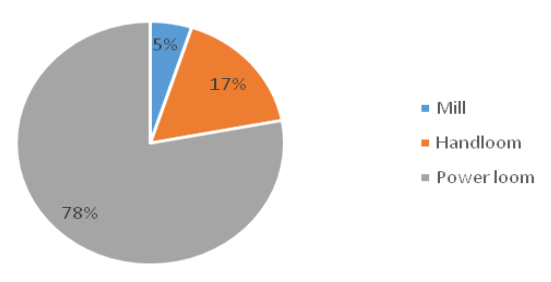

Table 2 shows that, In the 1990s, the major share of textile production (excluding hosiery, khadi, and wool) is from power loom i.e. 66 percentage, whereas handloom share is 22 percentage, in 2000 s, share of power loom and handloom increased to 72 and 23 respectively, but share of mill sector decreased.

Throughout the period 2009-2017, the share of the power loom, handloom and mill sector sectors constant i.e. nearly 80 percent, 15 percentage, and 5 percentage respectively. Chart 1 reveals that nearly the same percentages of cloth production from different sectors that are 78 percentage from power loom, 17 percentage from handloom and 5 percentage from mills in the year 2016-17.

Table 3: Trend of Handloom Cloth Production in India (Million Square Meters)

\begin{tabular}{|c|c|c|c|c|}
\hline Year & $\begin{array}{c}\text { Handloom } \\
\text { cloth }\end{array}$ & $\begin{array}{c}\text { Total } \\
\text { cloth* }\end{array}$ & $\begin{array}{c}\text { The growth rate of } \\
\text { handloom cloth }\end{array}$ & $\begin{array}{c}\text { \% Share of handloom to } \\
\text { total cloth }\end{array}$ \\
\hline $1980-81$ & 3109 & 12444 & - & 24.98 \\
\hline $1990-91$ & 4295 & 22928 & - & 18.73 \\
\hline $2000-01$ & 7472 & 40333 & - & 18.53 \\
\hline $2009-10$ & 6806 & 45819 & 1.93 & 14.85 \\
\hline $2010-11$ & 6907 & 61761 & 1.48 & 11.18 \\
\hline $2011-12$ & 6901 & 59605 & -0.09 & 11.57 \\
\hline $2012-13$ & 6952 & 61949 & 0.74 & 11.22 \\
\hline $2013-14$ & 7104 & 62624 & 2.19 & 11.34 \\
\hline $2014-15$ & 7203 & 64332 & 1.39 & 11.19 \\
\hline $2015-16$ & 7638 & 64584 & 6.04 & 12.61 \\
\hline $2016-17$ & 8007 & 63480 & 4.83 & $11-80$ \\
\hline $2017-18($ up to & 5134 & 43520 & - & \\
\hline Nov' 2018) & & & \\
\hline
\end{tabular}

(Souce: Ministry ofTextile Commission, Government of India)

*In total cloth production handloom, power loom and mill included but hosiery, khadi, and wool have not been considered.

Note: the growth rate is calculated w.r.t. the same period of last year 


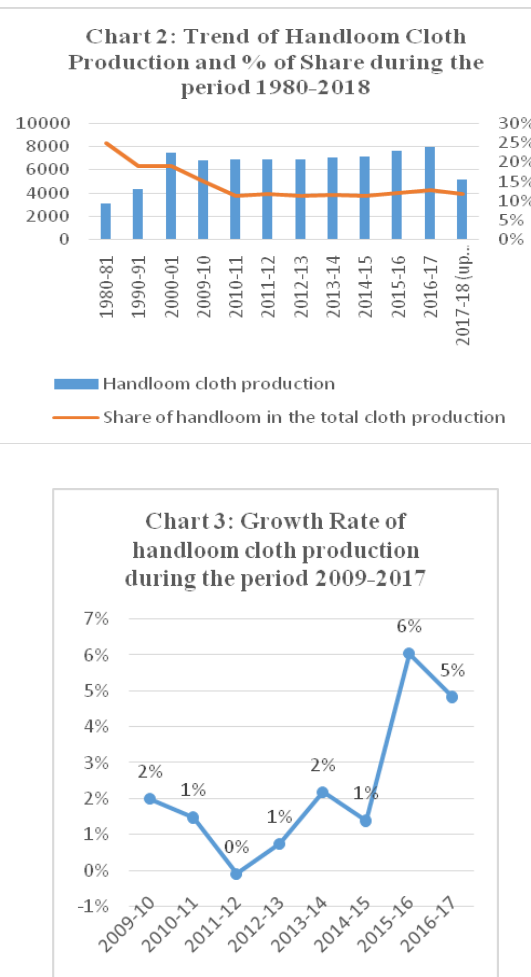

Table 3 and chart 2 shows that, In the 1980s, handloom cloth production is 3100 million sq. meters, and share of cloth production from the handloom sector to total cloth production is 25 percentage, it decreased to 19 percent in the $1990 \mathrm{~s}$, but handloom cloth production is increased to 4300 million sq. meters and it increased to 7400 million sq. meters in the 2000 s, but the almost same percent of share is maintained till the $2000 \mathrm{~s}$, but it sharply declined to 15 percentage till 2009-10. Share of handloom cloth has been stagnant i.e. nearly 11 to 12 percent during the period 2010-17. Handloom cloth production has been continuously increasing i.e. from 6806 million square meters in the year 2009-10 to 8007 million square meters in the year 2016-17,but whereas the growth rate of handloom cloth production has fluctuation.

Chart 3 shows, the growth rate line had fluctuated, it declined continuously during the period 2009-12, and it had recorded a negative growth rate in the year 2011-12, after that, it was shown increasing trend except in the years 2013-14 and 2016-17.

\section{EXPORT OF HANDLOOM PRODUCTS:-}

Indian handloom industry has grown up and occupied a lion share in the world market until the middle of the nineteenth century. Indian handloom sector holds a unique position, as similar sectors all over the world have closed down except in very few countries, handloom products have almost vanished from the world market. Share of the Indian handloom fabric in the world is $95 \%$ (Annual report 2016-17, Ministry of Textiles, GOI). India is the second largest exporter of handloom products in the world, with exports valued at US\$ 353.9 million in 2017 18 (Indian handloom industry: potential and prospects, EXIM Bank's working paper 80, 2018). The trend of export of handloom products during the period 2009-18 is as follows:

Table 4: Export of Handloom Products during the period 2009 - 2018(Values in US\$ Millions)

\begin{tabular}{|c|c|c|c|c|}
\hline Year & $\begin{array}{c}\text { Handloom } \\
\text { products }\end{array}$ & $\begin{array}{c}\text { Textile \& Allied } \\
\text { products }\end{array}$ & $\begin{array}{c}\text { The growth rate } \\
\text { of Handloom } \\
\text { products }\end{array}$ & $\begin{array}{c}\text { Share of handloom } \\
\text { products to textile \& } \\
\text { allied products }\end{array}$ \\
\hline $2009-10$ & 264.85 & 22418.78 & - & 1.18 \\
\hline $2010-11$ & 346.07 & 27747.98 & $30.67 \%$ & 1.25 \\
\hline $2011-12$ & 554.01 & 33310.21 & $60.09 \%$ & 1.66 \\
\hline $2012-13$ & 518.32 & 31705.53 & $-6.44 \%$ & 1.63 \\
\hline $2013-14$ & 373.01 & 39310.88 & $-28.03 \%$ & 0.95 \\
\hline $2014-15$ & 369.56 & 42192 & $-0.92 \%$ & 0.88 \\
\hline $2015-16$ & 368.52 & 35952.65 & $-0.28 \%$ & 1.03 \\
\hline $2016-17$ (Apr-Mar) & 359.73 & 35766.63 & $-2.39 \%$ & 1.01 \\
\hline $2016-17$ (Apr-Oct) & 210.91 & 19625.18 & - & 1.07 \\
\hline $2017-18$ (Apr-Oct) & 214.88 & 20411.65 & $1.88 \%$ & 1.05 \\
\hline
\end{tabular}

(Source: Foreign trade statistics of India (Principal commodities \& countries), DGCI\&S)

Note: 1.Growth rate is calculate w.r.t. the same period of last year.

2. Handloom products have been included as commodities first time in 2009-10.

Chart 4: Handloom products export trend in India during the period 2009-2018

(Figures in US\$ Millions)

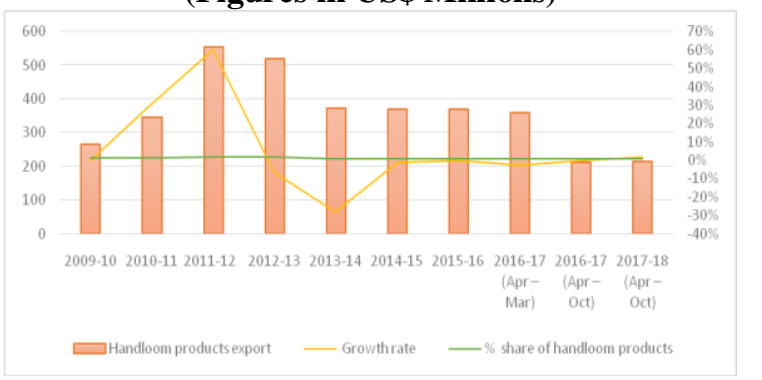

Table 4 and chart 4 reveals that export value of handloom products is $265 \mathrm{US}$ million dollars in the year 2009-10, and it is increased to 554 US million dollars in 2011-12, but it declined to 360 US million dollars in 2016-17, it is 215 US million dollars in 2017-18 (AprOct). The export of handloom products growth rate has not been impressive during the period 2009-18, it 
registered consistent decline from the year 2012 to 2017 , but in the year 2013-14 it has highest negative growth rate i.e. 28 percentage, and highest positive growth rate in the year 2011-12 i.e. 60 percentage. The share of the handloom products export line is consistent during the period 2009-2018 i.e. nearly 1 percentage.

Table 5: Handloom fabric wise export and growth rate during the period 2009-19(Values in INR Crores)

\begin{tabular}{|r|c|c|c|c|c|c|c|c|c|}
\hline \multirow{2}{*}{ Year } & \multirow{2}{*}{$\begin{array}{c}\text { Total } \\
\text { Handloo } \\
\text { m value }\end{array}$} & \multicolumn{2}{|c|}{ Fabrics } & \multicolumn{2}{c|}{$\begin{array}{c}\text { Floor } \\
\text { Coverings }\end{array}$} & \multicolumn{2}{c|}{$\begin{array}{c}\text { Clothing } \\
\text { Accessories }\end{array}$} & \multicolumn{2}{c|}{ Made-ups } \\
\cline { 5 - 11 } & Value & $\begin{array}{c}\text { Growth } \\
\text { rate }\end{array}$ & Value & $\begin{array}{c}\text { Growth } \\
\text { rate }\end{array}$ & $\begin{array}{c}\text { Value } \\
\text { Growth } \\
\text { rate }\end{array}$ & $\begin{array}{c}\text { Value } \\
\text { Growth } \\
\text { rate }\end{array}$ \\
\hline $2009-10$ & 1252.81 & 65.21 & - & 58.14 & - & 0.86 & - & 1128.58 & - \\
\hline $2010-11$ & 1574.95 & 71.48 & 9.62 & 147.02 & 152.87 & 3.20 & 272.09 & 1353.25 & 19.91 \\
\hline $2011-12$ & 2623.96 & 78.58 & 9.93 & 376.61 & 156.16 & 36.26 & 1033.13 & 2132.51 & 57.58 \\
\hline $2012-13$ & 2811.97 & 52.05 & -33.76 & 619.14 & 64.40 & 74.01 & 104.11 & 2066.77 & -3.08 \\
\hline $2013-14$ & 2233.11 & 59.63 & 14.56 & 948.61 & 53.21 & 66.71 & -9.86 & 1158.15 & -43.96 \\
\hline $2014-15$ & 2246.48 & 98.59 & 65.34 & 914.55 & -3.59 & 82.09 & 23.06 & 1151.25 & -0.60 \\
\hline $2015-16$ & 2353.33 & 231.49 & 134.80 & 819.82 & -10.36 & 165.71 & 101.86 & 1136.31 & -1.30 \\
\hline $2016-17$ & 2392.21 & 172.48 & -25.49 & 868.68 & 5.96 & 135.60 & -18.17 & 1215.45 & 6.96 \\
\hline $2017-18$ & 2280.19 & 124.24 & -27.97 & 787.72 & -9.32 & 95.50 & -29.57 & 1272.73 & 4.71 \\
\hline
\end{tabular}

(Source: Foreign trade statistics of India (Principal commodities \& countries), DGCI\&S)

\section{Chart 5: Product-wise share of handloom exports during the period 2009-18}

- Fabrics = Floor Coverings = Clothing Accessories Made-ups

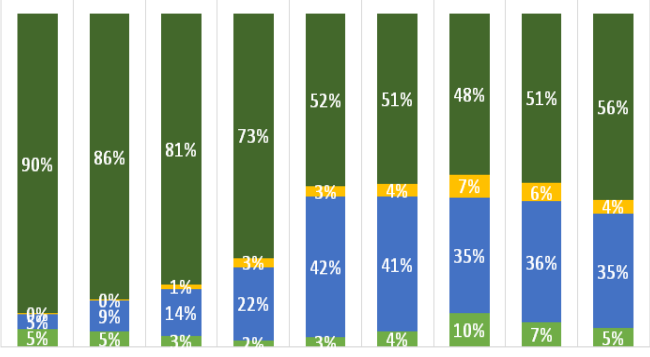

2009-102010-112011-12 2012-132013-142014-152015-162016-172017-18

Table 5 and chart 5 shows the handloom fabric wise such as fabrics, floor coverings, clothing accessories, and made-ups exports and their growth rates during the period 2009-2018.Made-ups value of exports and percent of shares in the total handloom exports is highest during the period 2009-18, its share consistently declined from 90 percent in the year 2009-10 to 56 percent in 2017-18. Floor coverings occupy the second place in the value of exports and share of total handloom exports, and its share had been consistently increased from 5 percentage in the year 2009-10 to42 percent in the year 2013-14, after that its share slowly declined to 35 percent in the year 2017-
18. Whereas shares and values of fabrics and clothing accessories are very little and negligible but their share has been slowly increasing during the above period.

If we observe the product-wise growth rates of handlooms exports from the above table during the period 2010-18, fabrics growth rate is consistent in the first two years, but in the next year it recorded negative growth rate i.e. 34 percentage, after that it increased till 2015-16, and recorded highest growth rate in the same year i.e.135 percentage, next to that year it recorded negative growth rates. The growth rate of floor covering, in the first two years recorded the highest growth rate during the period 2010-12 i.e. nearly $150 \%$, after that, it steeply declined and recorded negative growth rates except in the year 2016-17. The growth rate of clothing accessories has shown the highest fluctuations, it recorded the highest growth rate in the year 2011-12 i.e.1033 percentage and negative growth rates in the years 2013-14, 2016-17 and 2017-18. Whereas growth rate of made-ups has recorded very low even though their shares are high, and recorded negative growth rates continuously during the period 2012-16.

\section{IMPORT OF HANDLOOM PRODUCTS\& RESULTS:-}

Even though Indian handlooms hold a major chunk in the world market, some value of the handloom products have been importing as follows:

Table 6: Import of Handloom products during the period 2015-17(Values in US\$ Millions)

\begin{tabular}{|c|c|c|c|}
\hline Year & $\begin{array}{c}\text { Handloom } \\
\text { products }\end{array}$ & $\begin{array}{c}\text { Share of } \\
\text { Textile \& } \\
\text { Allied } \\
\text { products } \\
\text { handloom } \\
\text { products } \\
\text { to textile } \\
\text { \& allied } \\
\text { products }\end{array}$ \\
\hline
\end{tabular}




\begin{tabular}{|c|c|c|c|}
$\begin{array}{c}2015- \\
\begin{array}{c}16(\text { Apr- } \\
\text { Mar) }\end{array}\end{array}$ & 10.43 & 5332.57 & 0.20 \\
\hline $\begin{array}{c}2016-17 \\
\text { (Apr-Mar) }\end{array}$ & 5.35 & 5516.64 & 0.10 \\
\hline $\begin{array}{c}2016-17 \\
\text { (Apr-Oct) }\end{array}$ & 2.82 & 3490.14 & 0.08 \\
\hline $\begin{array}{c}2017-18 \\
\text { (Apr-Oct) }\end{array}$ & 5.41 & 3873.79 & 0.14 \\
\hline
\end{tabular}

(Source: Handloom export promotion council, Ministry of textiles, GOI)

Table 6 shows that the import value of handloom products is nearly 10 million US\$s in the year 2015-16 and it declined to 5 million US\$s in the next year, again it recorded 5 million US\$s in the first seven months of the year 2017-18. But the share of handlooms in the total imports of textile \& allied products is negligible.

\section{CONCLUSION:-}

The study reveals that most of the elements of the handloom sector are not impressive. Handloom units, weavers \& allied workers, looms, the share of handloom cloth in total cloth production, handloom exports, export share in total textile \& allied products are declined and share of idle looms increased from the 1980s to 2010s.It indicates that, migration of handloom workers to other profession, younger generation is not interested to take handloom as a profession, low productivity, lagging behind technology, low income generation, inadequate production infrastructure, health problems, competition from organized power loom and mill sector, insufficient marketing infrastructure, lack of initiation in export, and lack of government support.

\section{SUGGESTIONS:-}

Weavers have to change their attitude from traditional to modern. Change of designs as per market requirements, creation of a local brand image, and quality in products, product innovation and utilization of modern technology in marketing strategies enhance the domestic and international market. Up-gradation of technology in production activities, maintenance of specific work hours, development of production infrastructure and skill development improves the production as well as quality. The government has to implement skill development programs, create awareness on technological changes that are suitable for the handloom industry, financial support for up-gradation of technology, providing credit facilities, development of marketing facilities, strategies for ensuring confidence in youth for taking handloom as a profession.

\section{REFERENCES}

1. The Reservation of Articles for Production Act, 1985.

2. Handloom Census of India 2009-10, Development Commissioner (Handlooms), Ministry of Textiles, Government of India.

3. Annual Report 2017-18, Ministry of Textiles, Government of India.

4. Mr. Ashish Kumar, Ms. SimaranKaur (2018), Indian Handloom Industry: Potential and Prospects, ExportImport Bank of India, Working Paper No. 80.
5. Shilpi Jain, SripurnaBasu, BishkaMajumdar, (2018), Digital Empowerment for Handloom Clusters: The Case of Digital Cluster Development Program in India, International Journal of Management and Applied Science, Volume.4, Issue 14.

6. Thirupathi Kandikonda1 and AnakamSreenivas, (2017), Handloom Industry in Telangana State - An Overview, International Journal of Management and Development Studies, 6(4): 38-43.

7. Dr. Esha Jain, AshankYadav (2017), Marketing and Technology: Role of Technology in Modern Marketing, Journal of Business and Management, Volume 19, Issue 5. Pp. 49-53.

8. A. Arul Prakash, Dr.A.Selvendran, (2017), research study concentrated on the Kanchipuram silk handloom sarees in the research paper "A Study on Present Scenario of Silk Handloom Industry in Kanchipuram District, Tamilnadu".

9. Dr. SabihaKhatoon (2016), Make in India: A Platform to Indian Handloom Market, Journal of Business and Management, Volume 18, Issue 9, pp. 36-40,

10. KalyanSarkar (2016), A Study on Health Issues of Weavers (Handloom Weaving), International Journal of Technology \& Management, Volume 3, Issues 11.

11. Dr. SumanaChatterjee (2015), An overview of the small scale units in the textile sector of Gujarat, International Journal of Research in Engineering, IT \& Social Sciences, Volume 5, Issue 6.

12. BhabeshHazarika, MadhurjyaPrashadBezbaruah, KishorGoswami (2016), Adoption of modern weaving technology in the handloom micro-enterprises in Assam: A Double Hurdle approach,Technological forecasting \& social change, 102 , pp.344-356

13. TasneemShazli (2014), Female Work Participation in Handloom Industry - A Case Study of Mubarakpur Town, Azamgarh District, U.P., Journal of Education \& Social Policy, Volume 1, No.1.

14. Dr. RachanaGoswami, Dr. Ruby Jain (2014), Strategy for Sustainable Development of Handloom Industry, Global Journal of Finance and Management, Volume 6, No. 2, pp. 93-98.

15. Alin Borah Bortamuly, KishorGoswami, BhabeshHazarika, KalpanaHandique(2014), Do different determinants affect differently across gender and location in handloom entrepreneurship development?, Journal of Small Business \& Entrepreneurship, 27:5, 427-449.

16. G. Savithri, P.Sujathamma, Tripura Sundari and B. Chandan Kumar (2014),An unique silk handloom cluster, International Journal of Multidisciplinary Research and Development, 1(7),pp. 418-421.

17. NoopurTandan, E Eswara Reddy, (2013), A Study on Emerging Trends in Textile Industry in India, International Journal of Advancement in Research \& Technology, Volume 2, Issue 7. 
18. Dr. SrinivasaRaoKasisomayjula (2012), Socio-economic analysis of the handloom industry in Andhra Pradesh A Study on selected districts, Journal of Exclusive Management Science, Volume 1, Issue 8.

19. Suresh Bhagavatula, Tom Elfring, Aadvan Tilburg, Gerhard G. Van de Bunt (2010), How social and human capital influence opportunity recognition and resource mobilization in India's handloom industry, Journal of Business Venturing, Volume 25, Issue 3, pp. 245-260.

20. AlokNath Roy, GautamBasu (2009), Improvement of a traditional knowledge by development of jacquard shedding based handloom for weaving ornamental jute fabric, Indian Journal of Traditional Knowledge, Volume 9(3), pp. 585-590.

21. KKN Kurup (2008), Traditional handloom industry of Kerala, Indian Journal of Traditional Knowledge, Volume 7(1), pp. 50-52.

22. Dharmaraju P (2006), Marketing in Handloom Cooperatives, Economic and Political Weekly, Volume 41, No. 31, pp. 3385-3387.

23. SeemanthiniNiranjan, SoumyaVinayan (2001), Report on Growth and Prospects of the Handloom Industry, Planning Commission for Dastkar Andhra.

24. RatanKhasnabis, Pranab Nag (2001), Labour Process in the Informal Sector - A Handloom Industry in Naidal District, Economics \& Political Weekly, Volume 36, No. 52.

25. AnupamaTakur (1995), A Frame Work for Analysis of Handloom Industry, Vikalpa, Volume 20, No.3.

26. Clark Nardinelli (1986), Technology and Unemployment: The Case of the Handloom Weavers, Southern Economic Journal, Volume 53, No.1, pp.87-94.

27. Status Quo in the Definition Of Handloom Under Handloom Reservation Act, Ministry of Textiles, Press information bureau, Government of India.

28. http://ministryoftextiles.gov.in/

29. https://www.hepcindia.com/

30. https://commerce.gov.in/Index.aspx

31. http://handlooms.nic.in/Default.aspx?ReturnUrl=\%2f

32. http://www.ncaer.org/publication_details.php?pID=187 